IOSR Journal of Pharmacy

e-ISSN: 2250-3013, p-ISSN: 2319-4219, www.iosrphr.org

Volume 2 Issue 6 || || Nov-Dec. 2012 || || PP.60-64

\title{
Irrigational Impact Of Distillery Spentwash On The Germination And Growth Of Jatropha (Jatropha Curcas)And Sunflower (Helianthus Annuus) Oil Seed Plants
}

\author{
S. Chandraju ${ }^{* 1}$, Siddappa ${ }^{1}$, C. S. Chidan Kumar ${ }^{2}$ \\ ${ }^{3}$ S. S. Shree Harsha Kumar \\ ${ }^{1}$ Department Studies in Sugar Technology, Sir M.Vishweshwraya Post Graduate Center, \\ University of Mysore, Tubinakere-571402, Karnataka, India. \\ ${ }^{2}$ Department of Engineering Chemistry, Alva's Institute of Engineering \& Technology, \\ Shobhavana Campus, Mijar, Moodbidri -574225, South Canara Dt. Karnataka, India \\ ${ }^{3}$ College of Agriculture, University of Agricultural Sciences Dharwad, \\ Bijapur-586101, Karnataka India.
}

\begin{abstract}
Germination of Jatropha (Jatropha curcas) and Sunflower (helianthus annuus) seeds was made by irrigated with distillery spentwash of different concentration. The spentwash i.e. primary treated spentwash [PTSW] 1:1, 1:2 and 1:3 spentwash were analyzed for their plant nutrients such nitrogen, phosphorous, potassium and physical \&chemical characteristics. Experimental soil was tested for its physicochemical parameters. Jatropha and Sunflower seeds were sowed in the prepared land and irrigated with raw water (RW), 1:1, 1:2 and 1:3 spent wash. The nature of germination and growth of seed was studied, It was found that, the germination as well as growth was good(100\%) in 1:3 SW irrigation, while very poor in 1:1 $S W(25 \%)$,moderate in 1:2 SW(80\%) and 95\% in RW irrigation.
\end{abstract}

Keywords—Distillery spentwash, Jatropha seed, germination, Irrigation, Soil.

\section{INTRODUCTION}

Jatropha (Jatropha curcus) is a genus of approximately 175 succulent plants, shrubs and trees from the family of euphorbiraceae. Jatropha as one of the best for future bio-diesel production. It is resistant to drought and pests and produces seeds containing $27-40 \%$ oil, averaging $34.4 \%$. the remaining press cake of jatropha seeds after oil extraction could also to be considered for energy production the stems of haats (jatropha cuneeta) are used for basket making by seri people in Sonora, Mexico, the stems are roasted, split and soaked through an elaborate process. Currently the jatropha seeds is used for making bio-diesel fuel in Philippines and in Brazil.

The jatropha oil being promoted as an easily grown bio fuel crop in hundred of projects throughout india. The side of the railway line between Delhi and Mumbai is planted with jatropha and the train runs on 15$20 \%$ bio-diesel.

In recent days oils are used as fuel in automobile engines by converting oil into esters by transesterificaction method[1,2,3]

Once the seeds have been pressed, the remaining cake can be used as feed in digesters gasifiers to produce biogas for cooking and in engines or be used for fertilizer and some time even as animal fodder.[4,5]

Sunflower(helianthus annuus) seed are more commonly eaten as a healthly snack than as part of a meal. they can also be used as garnishes in various recipes. The seeds may be sold as in shell seedsor de-hulled kernels. Sunflower seeds are also an excellent source of dietary fiber. Some amino acids(especially tryptophan) vitamin E\&B, vitaminB5 and minerals such as copper, manga nese, potassium, iron, selenium, calcium and zinc. Additionally, they are rich in cholesterol-lowering phytosterol [6.7].

Molasses (one of the important byproduct of sugar industry) is the main source for the production of Ethanol in distilleries by fermentation method. About 08 (eight) liters of waste water is generated for every liter of ethanol production in distilleries, known as raw spentwash(RSW) which is characterized by high biological oxygen demand (BOD:5000-8000 mg/L) and chemical oxygen demand (COD :25000-30000 $\mathrm{mg}$ dangerous /L) [8] undesirable color. Discharge of raw spentwash into open land or nearby water bodies is, since it results in number of environmental, water and soil pollution including threat to plant and animal lives. The RSW is highly acidic and contains easily oxdisable, organic matter with very high BOD and COD[9] .Also, spent wash contains high organic nitrogen and nutrients[10], By installing biomethenation plant in distilleries, reduces the 
oxygen demand of RSW, the resulting spentwash is called primary treated spent wash(PTSW) and primary treated to RSW increases the nitrogen $(\mathrm{N})$, phosphorous $(\mathrm{P})$ and potassium $(\mathrm{K})$ and decreases calcium $(\mathrm{Ca})$, magnesium $(\mathrm{Mg})$, sodium $(\mathrm{Na})$, chloride $\left(\mathrm{Cl}^{-}\right)$, and sulphate[11] ,The PTSW is rich in potassium $(\mathrm{K})$, sulphur $(\mathrm{S})$, $\operatorname{Nitrogen}(\mathrm{N})$, Phosphorous $(\mathrm{P})$, as well as easily bio degradable organic matter and its application to soil has been reported to increase the yield of sugarcane[12], rich[13] wheat, rice yield[14], quality of groundnut[15] and physiological response of soybean[16]. Diluted spentwash could be used for irrigation purpose without adversely affecting soil fertility[17-18], seed germination and crop productivity[19]The diluted spentwash irrigation improved the physical and chemical properties of the soil and further increased soil micro flora[20]. Twelve pre-sowing irrigations with the diluted spentwash had no adverse effect on the germination of maize but improved the growth[21]. Diluted spent wash increases the growth of shoot length, leaf number per plant, leaf area and chlorophyll content of peas[22] .Increased concentration of spentwash causes decreased seed germination, seedling growth and chlorophyll content in sunflowers (Helianthus annuus) and the spentwash could be safel used for irrigation purpose at lower concentration[23-24]. The spent wash contained in excess of various forms of cations, anions, which are injurious to plant growth and these constituents should be reduced to beneficial level by diluting the spentwash, which can be used as substitute for chemical fertilizer[25]' the spentwash could be used as a compliment to mineral fertilizer to sugarcane[26].The spent wash contained N, P, $\mathrm{K}, \mathrm{Ca}, \mathrm{Mg}$ and $\mathrm{S}$ and thus valued as a fertilizer when applied to soil through irrigation with water[27]. The application of diluted spentwash increased the up take of Zinc ( $\mathrm{Zn})$, Copper $(\mathrm{Cu})$, Iron (Fe), Manganese (Mn) in Maize and wheat as compared to control and the highest total uptake of these were found at lower dilution levels than at higher dilution levels[28] growth of cotton and groundnut, leaves vegitables[29-30] Mineralization of organic material as well as nutrients present in the spent wash were responsible for increased availability of plant nutrients. However no information is available on the studies on the impact of irrigation of spentwash on the Germination and growth of jatropha (jatropha curcas) oil seed plants. Therefore, the present investigation was carried out to to study the influence of different proportions of spentwash on Germination and growth of jatropha and Sunflower seeds.

\section{MATERIALS AND METHODS}

Field work was conducted at own land in Halebudanur village near Mandya, Karnataka. Before cultivation, a composite soil sample was collected from experimental site at $25 . \mathrm{cm}$ depth at different sites, mixed and dried under sunlight. The sample was analyzed by standard procedures (Table-1). The PTSW was used for irrigation with a dilution of 1:1, 1:2 and 1:3 ratios. The physical and chemical characteristics and amount of nitrogen(N) Potassium(K), Phosphorous(P) and sulphur (S) present in the PTSW, 1:1, 1:2 and 1:3 distillery spent wash were analyzed using standard procedures (Table-2 and 3).

Table- 1Physico-Chemical Properties of Soil

\begin{tabular}{|c|c|c|}
\hline Parameters & 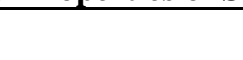 & Values \\
\hline Coarse sand c & & 9.85 \\
\hline Fine sand ${ }^{\circ}$ & & 40.72 \\
\hline Slit $c$ & & 25.77 \\
\hline Clay ${ }^{c}$ & & 23.66 \\
\hline $\mathrm{PH}(1: 2$ soln $)$ & & 8.41 \\
\hline Electrical Conductivity a & 540 & \\
\hline Organic Carbon ${ }^{\circ}$ & 1.77 & \\
\hline Available Nitrogen ${ }^{b}$ & & 402 \\
\hline Available Phosphorous ${ }^{b}$ & 202 & \\
\hline Available Potassium ${ }^{b}$ & & 113 \\
\hline Exchangable Calcium $^{b}$ & 185 & \\
\hline Exchangable Magnesium ${ }^{b}$ & 276 & \\
\hline Exchangable Sodium ${ }^{b}$ & 115 & \\
\hline Available Sulphur ${ }^{b}$ & & 337 \\
\hline DTPA Iron ${ }^{b}$ & & 202 \\
\hline DTPA Manganese $b$ & & 210 \\
\hline DTPA Copper ${ }^{b}$ & 12 & \\
\hline DTPA Zinc ${ }^{b}$ & 60 & \\
\hline Units: a-ms & $c-\%$ & \\
\hline
\end{tabular}


Table-2 Chemical Characteristics of Distillery Spent wash at different Dilution

\begin{tabular}{|c|c|c|c|c|c|c|}
\hline Chemical parameters & & & 1 PTSW & 1:2 PTS & SW & $1: 3 \mathrm{P}$ \\
\hline PH & 7.57 & 7.63 & 7.65 & & 7.66 & \\
\hline Electri & & & 17260 & 7620 & & 5330 \\
\hline Total solids & & & 27230 & 21930 & & 15625 \\
\hline Total dissolved solids ${ }^{b}$ & 37100 & 18000 & 12080 & & 64520 & \\
\hline Total suspended solids ${ }^{b}$ & 10240 & 5830 & 2820 & & 1250 & \\
\hline Settle able solids ${ }^{b}$ & & & 4150 & 4700 & & 3240 \\
\hline $\mathrm{COD}^{\mathrm{b}}$ & & & 19036 & 4700 & & 2140 \\
\hline$B O D^{b}$ & & & 7718 & 4700 & & 2430 \\
\hline Carbonate $^{b}$ & & & Nil & Nil & & Nil \\
\hline Bicarbonate $^{b}$ & & & 6500 & 3300 & & 1250 \\
\hline Total Phosphorous ${ }^{b}$ & & & 22.44 & 17.03 & & 10.80 \\
\hline Total potassium ${ }^{b}$ & 7500 & 4000 & 2700 & & 1620 & \\
\hline Calcium $^{b}$ & & & 590 & 370 & & 190 \\
\hline Magnesium $^{b}$ & & 16476.16 & 134.22 & & 85 & \\
\hline Sulphur ${ }^{b}$ & & & 30.2 & 17.8 & & 8.4 \\
\hline Sodium ${ }^{b}$ & 520 & 300 & 280 & & 140 & \\
\hline Chlorides ${ }^{b}$ & & & 3512 & 3404 & & 2960 \\
\hline Iron $^{b}$ & & & 4.7 & 3.5 & & 2.1 \\
\hline Manganese ${ }^{b}$ & & & 495 & 288 & & 160 \\
\hline $\operatorname{Zinc}^{b}$ & & & 0.94 & 0.63 & & 0.56 \\
\hline Copper ${ }^{b}$ & & & 0.108 & 0.048 & & 0.026 \\
\hline Cadmium ${ }^{b}$ & & & 0.003 & 0.002 & & 0.001 \\
\hline Lead ${ }^{b}$ & & & 0.09 & 0.06 & & 0.003 \\
\hline Chromium $^{b}$ & & & 0.026 & 0.012 & & 0.008 \\
\hline Nickel $^{b}$ & 0.09 & 0.045 & 0.025 & & 0.012 & \\
\hline Ammonical Nitrogen $b$ & 750.8 & 352.36 & 283.76 & & 178 & \\
\hline Carbohydrates $^{\mathrm{C}}$ & 22.80 & 11.56 & 8.12 & & 6.20 & \\
\hline
\end{tabular}

Units: a $-\mu \mathrm{S}, \quad$ b-mg L, c- $\%$, PTSW - Primary treated spentwash

Table-3 Amount of N, P, K and $S$ (nutrients) in Spentwash

\begin{tabular}{|c|c|c|c|c|c|c|}
\hline Chemical Parameters & PTSW & 1:1 PTSW & & 1:2 PTS & $1: 3$ & \\
\hline Ammonical Nitrogen ${ }^{\mathrm{a}}$ & & 750.8 & 352.36 & & 283.76 & 160.5 \\
\hline Total Phosphorous ${ }^{\mathrm{a}}$ & & 40.5 & 22.44 & & 17.03 & 11.2 \\
\hline $\begin{array}{l}\text { Total Potassium } \\
\text { Sulphur }\end{array}$ & 7500 & $70^{4000}$ & 30.2 & $\begin{array}{r}2700 \\
17.8\end{array}$ & & \\
\hline
\end{tabular}

Unit: a-mg L, PTSW: Primary treated spent wash

Table-4 Germination and growth of Jatropha and sunflower at different irrigation $(\mathrm{cm})$

\begin{tabular}{|c|c|c|c|c|c|}
\hline \multirow{3}{*}{ Plant } & \multirow{3}{*}{$\begin{array}{l}\text { RW } \\
1: 3 \text { PTSW } \\
15^{\text {th }} 22 \text { th } \\
2_{\text {th }}{ }^{9^{\text {th }}} \\
\text { Dav }\end{array}$} & $\begin{array}{l}1: 1 \text { PTSW } \\
15^{\text {th }} 22 \text { th }\end{array}$ & & 1:2 PTSW & $15^{\text {th }} 22$ th \\
\hline & & $29^{\text {th }}$ & $29^{\text {th }}$ & & $29^{\text {th }}$ \\
\hline & & Day & Day & Day & \\
\hline Jatropha & $1.2,2.5,8.9$ & $1.0,1.2,5.8$ & $1.2,4.7,7.9$ & & \\
\hline Sunflower & $1.5,2.1,8.0$ & $1.0,1.1,4.5$ & $1.4,3.6,6.5$ & & \\
\hline
\end{tabular}


Oil seed plants selected for the present investigation was Jatropha and sunflower. The seeds were sowed and irrigated (by applying $5-10 \mathrm{~mm}^{3} / \mathrm{cm}^{2}$ depends upon the climatic condition) with raw water (RW), 1:1,1:2 and 1:3 SW at the dosage of twice a week and rest of the period with raw water depend upon the climatic condition. Trials were conducted for three times and average growth were recorded (Table-4).

\section{RESULTS AND DISCUSSION}

Characteristics of experimental soils such as $\mathrm{pH}$, electrical conductivity, the amount of organic carbon, available nitrogen $(\mathrm{N})$, phosphorous(p), Potassium $(\mathrm{K})$, sulphur $(\mathrm{S})$, exchangeable calcium $(\mathrm{Ca})$, Magnesium $(\mathrm{Mg})$, Sodium(Na), DTPA iron $(\mathrm{Fe})$, manganese $(\mathrm{Mn})$, copper $(\mathrm{Cu})$ and zinc $(\mathrm{Zn})$ were analyzed and tabulated (Table1). It was found that the soil composition is fit for the cultivation of plants, because it fulfils all the requirements for the growth of plants. Chemical composition of PTSW, 1:1,1:2 and1:3 SW such as pH, electrical conductivity, total solids (TS), total dissolved solids (TDS), total suspended solids(TSS), settelable solids (SS), chemical oxygen demand(COD), biological oxygen demand(BOD), carbonates, discarbonates, total phosphorous $(\mathrm{P})$, total potassium $(\mathrm{K})$, ammonical nitrogen $(\mathrm{N})$, calcium $(\mathrm{Ca})$ magnesium $(\mathrm{Mg})$, sulphur $(\mathrm{S})$, Sodium(Na), chlorides $(\mathrm{Cl})$, iron(Fe), Manganese(Mn), zinc( $\mathrm{Zn})$, copper $(\mathrm{Cu})$, cadmium $(\mathrm{Cd})$, lead $(\mathrm{Pb})$, chromium $(\mathrm{Cr})$ and nickel $(\mathrm{Ni})$, were analyzed and tabulated (Table-2). Amount of N, P, K and S contents are presented in Table-3

The germination was good $100 \%$ in $1: 3 \mathrm{SW}, 25 \%$ in $1: 1 \mathrm{SW}, 80 \%$ in $1: 2 \mathrm{SW}$ and $95 \%$ in RW irrigations. Growth rate was very poor in 1:1 SW irrigation compare with RW, 1:2 SW and 1:3 SW irrigations. Maximum growth was observed in 1:3 SW compare to RW, 1:1 SW and 1:2 SW irrigations.

Germination and growth of Jatropha (jatropha curcas) and sunflower(helianthus annuus) was good (100\%) in 1:3 SW irrigation, while very poor in 1:1 SW (25\%), moderate in 1:2 SW (80\%) and $95 \%$ in RW irrigations. In 1:1 dilution, the germination was very poor $(25 \%)$. This could be due to the high concentration of spentwash makes mask on upper layer of soil, through which the seeds may not sprout within the stipulated time and spoil. But in 1:3 dilution 100\% germination was observed, this could be due to the sufficient quantity of moisture and plant nutrients available to seeds.

\section{CONCLUSION}

It concludes that, the spentwash, can be conviniently used with proper dilution for irrigation purpose without the nature of soil, environmental pollution and without using any external fertilizers(organic or inorganic).

\section{ACKNOWLEDGEMENTS}

The authors are thankful to The Nijaveedu Sugars Ltd., Koppa, Maddur Tq. Karnataka, for providing spentwash.

\section{REFERENCES}

[1]. Wikipedia encyclopedia

[2]. Friends of Earth Europe: Biofuel, Wonder crop, Jatropha. 21-01-2011.

[3]. Fairless D, "Biofuel the little shrub that could may be nature 2009. 449(1163):652-655.

[4]. Achlen W M J, Mathij and Singh V P,Biodeisel Fueling Sustainability, Biofuelbio produced, 2007. 1.(4): $283-291$.

[5]. Biodiesel under plant could spell doom for Kenya. 2010. Retried 2011-03-22.

[6]. FAO: major food and agricultural commodities and producers,

[7]. Science Daily: Sunflower seeds, pistachios Among Top Nuts For Lowering Cholesterol.

[8]. Joshi, H. C, Kalra, N, Chaudari, A and Deb, D L. Environmental issues related with distillery effluent utilization in agriculture in India, Asia Pac J . Environ.Develop,1994. 1:92-103.

[9]. Patil, J D, Arabetti, S .V and Hapse, D G. A review of some aspects of distillery spent wash (Vinase) utilization in sugarcane. Bhartiya Sugar: May.1987. 9-1-5.

[10]. Ramadurai, R . Gerard, R.J . SISSTA Sugar,J 1994..20,129.

[11]. Mohamed Haroon, A. R . Subhash Chandra Bose, M. Use of distillery spent wash for alkali soil reclamation, treated distillery effluent for ferti irrigation of crops. Indian form, March 2004. 48-51.

[12]. zalawadia N M, Ramana S, and Patil, R .G. Influence of diluted spentwash for sugar industries application on yield and nutrient uptake by sugarcane changes in soil properties. J.Indian soc. Soil.Sci. 1997. 1: 45, 767.

[13]. Devarajan L, Oblisami, G ,Kisan. Madras. 1995.82.664.

[14]. Pathak H , J. Indian Soc. Soil Sci.,1998. 46, 155.

[15]. Singh ,A.B Biswas, A, and Ramana, S. J.Plant Nutr.soil sci. 2003.166.345.

[16]. Ramana, S, Biswas A. K, Kundu,S, Saha, J.K, and Yadava, R.B.R. Effect of effluent on seed germination in some vegetable crops. Bio-resource Technology. 2002. 82:3.273-275.

[17]. [17] Kaushi, K, Nisha R, Jagjeet K, and Kaushik, C P. Impact of long and short term irrigation of sodic soil with distillery effluent in combination with bio-amendments. Bio- Resource technology 2005. 96: 17,1860-1866.

[18]. [18] Hatti ,K.M . Biswas,A.K, Bansypadhyay K, and mishra,A.K. J.plant nutr . soil sci. 2004.167,584. 
[19]. Revekar, K .P, Ramana S, Singh , A .B, Biswas ,K and Kundu S. Impact of post methanated spentwash(PMS) on the nursery raising, biological parameters of Glyricidia sepum and biological activity of soil. Ann. Plant Res.2000. 2(2), 161-168.

[20]. Ramana,S, Biswas,A,K Kundu, S. Saha ,J.K and Yadava, R.B.R. Effect of distillery effluent on seed germination in some vegetable crops. Bio-resource Technology.2001.82:3. 273-275.

[21]. Devarajan,L, Rajanan,G. Ramanathan and ,Oblisami, G, Kisan World, 1994.21,48.

[22]. Singh, Y, Raj Bahadur, effect of application of distillery effluent on maize crop and soil properties. Indian J.Agri Science 1998. 68: 70-74.

[23]. Rani,R, and Srivastava, M.M .Indian. J,Ecol.environ.sci. 1990.16,23.

[24]. Rajendran, K. Effect of ditillery effluent on the seed germination, seedling growth Chlorophyll content and mitosis in Helianthus annuus-Indian Botanical Contactor, 1990. 7:139-44.

[25]. Sahai,R, Jabeen,S and Saxena. P.K.Indian.J.Ecol.,1983. 10, 7.

[26]. Chares. S. Sugarcane, 1990.I,20

[27]. Samuel, G. The use of alcohol distillery waste as fertilizer, proceedings of international American Sugarcane Seminor,1996. Pp 245-252

[28]. Somashekar, R.K, Gowda, M.T.G and Shettigar S.I.N.Indian.J.

Environ.Health,1984.26,136.

[29]. Chandraju,S, Siddappa and Chidan kumar, C.S. Studies on the germination and growth of Cotton and Ground nut seeds irrigated by distillery spentwash,current Botany, 2011. 2(3):38-42

[30]. Basavaraju, H.C.and Chandraju,S . Impact of distillery spentwash on seed

[31]. Germination and growth of leaves Vegetables an investigation.sugar Journal

[32]. (SISSTA). 2007. 38: 20-50. 